\title{
Analisis tingkat kesehatan bank dengan metode camel (capital, assets quality, management, earnings, liquidity) pada pt bank kalteng
}

\author{
Muhammad Alief Akbar ${ }^{1)}$, Rita Sarlawa ${ }^{2)}$ \\ Fakultas Ekonomi dan Bisnis Universitas Palangka Raya, Indonesia
}

\begin{abstract}
Abstrak
Tujuan, - Penelitian ini ditujukan untuk mengetahui tingkat kesehatan PT Bank Kalteng ditinjau dengan metode CAMEL

Desain/Methodologi/Pendekatan - Analisis data yang digunakan adalah analisis CAMEL. Sumber data dalam penelitian ini adalah pada laporan publikasi keuangan yang dapat di akses melalui website resmi bank kalteng. Metode pengumpulan data dalam penelitian ini adalah dokumentasi yakni pengumpulan data dengan cara mengumpulkan data sekunder yang telah didokumentasikan yang berupa laporan keuangan tahunan.

Temuan penelitian - Hasil penelitian menunjukan bahwa, aspek permodalan (Capital) hasil rasio CAR terkategorikan sehat. Kualitas aset (Assets Quality) hasil rasio KAP terkategorikan sehat. Manajemen hasil rasio NPM (Net Profit Margin) terkategorikan sehat. Rentabilitas (Earnings) hasil rasio ROA dan BOPO terkategorikan sehat. Likuiditas (Liquidity) hasil rasio LDR terkategorikan sehat. Ini menunjukan bahwa penilaian tingkat kesehatan dengan metode CAMEL pada PT Bank Kalteng tergolong sehat.
\end{abstract}

Kata kunci: Tingkat Kesehatan Bank dan Rasio CAMEL

Jenis artikel: Artikel penelitian

\section{The analysis of bank soundness level with camel method (capital, assets quality, management, earnings, liquidity) at pt bank kalteng}

\begin{abstract}
Purpose, - This study aims to determine the soundness level of the bank at PT. Bank Kalteng for the period 2016 - 2019 using CAMEL analysis.

Design/methodology/approach - The data analysis used is the CAMEL analysis. The source of data in this study is the financial publication reports which can be accessed through the official website of the Central Kalimantan bank. The data collection method in this study is documentation, namely data collection by collecting documented secondary data in the form of annual financial reports.

Findings - The results showed that the capital aspect (Capital) resulted from the CAR ratio was categorized as healthy. The asset quality (Assets Quality) from the KAP ratio is categorized as healthy. Management of the results of the NPM (Net Profit Margin) ratio is categorized as healthy. Profitability (Earnings) from the ROA and BOPO ratio is categorized as healthy. Liquidity (LDR) ratio results are categorized as healthy. This shows that the assessment of the health level using the CAMEL method at PT Bank Kalteng is classified as healthy.
\end{abstract}

Keywords: Bank Soundness Level and CAMEL Ratio.

Paper type: Research Paper 


\section{Pendahuluan}

Krisis yang terjadi dalam beberapa tahun terakhir yang melanda Indonesia menyebabkan jatuhnya sektor perekonomian. Mulai dari nilai tukar Rupiah terhadap dolar Amerika Serikat yang mengalami pelemahan hingga terjadinya pandemi yang tentunya berujung pada jatuhnya perekonomian suatu negara.

Pada tahun 2018, Nilai tukar Rupiah pernah jatuh ke level Rp15.200 per USD pada bulan Oktober, namun di penghujung tahun bisa menguat lagi ke level Rp14.500-an per USD. Dilansir dari laman Bank Indonesia, nilai tukar Rupiah per Desember 2018 berada di level Rp14.481 per USD. Nilai tukar Rupiah tercatat melemah Rp939 atau 6,9\% dalam setahun (Mulyani, 2018). Belum lagi krisis pandemi yang sedang terjadi dan tentunya berdampak bagi perekonomian masyarakat yang mengalami pemutusan hubungan kerja sehingga meningkatkan pengangguran serta kemiskinan yang bertaraf global.

PT Bank Kalteng merupakan lembaga yang bergerak dibidang layanan jasa perbankan. Bank Kalteng merupakan salah satu bank yang telah memegang peranan penting terhadap kemajuan Kalimantan Tengah sejak mulai didirikannya. Sebagai bank yang memiliki peranan penting terhadap perekonomian daerah, Bank Kalteng juga merupakan lembaga yang peduli terhadap perkembangan Usaha Mikro Kecil Menegah (UMKM) demi menaikkan tingkat perekonomian daerah khususnya Kalimantan Tengah.

Berikut ini data yang menggambarkan kinerja keuangan Bank Kalteng, dapat dilihat pada tabel berikut:

Tabel 1. Kinerja Bank Kalteng

\begin{tabular}{|c|c|c|c|}
\hline No & Tahun & Laba Bersih setelah pajak & Total Aset \\
\hline 1 & 2016 & 190.245 & 5.858 .589 \\
\hline 2 & 2017 & 208.025 & 6.226 .933 \\
\hline 3 & 2018 & 226.980 & 7.860 .362 \\
\hline 4 & 2019 & 207.374 & 9.065 .881 \\
\hline
\end{tabular}

Sumber : (Annual Report Bank Kalteng 2019)

Berdasarkan tabel di atas dapat disimpulkan bahwa total laba bersih setelah pajak yang dimiliki oleh Bank Kalteng perlahan mengalami pertumbuhan dari tahun ke tahun berikutnya walaupun terjadi penurunan laba pada tahun 2018 di bandingkan dengan tahun sebelumnya. Sedangkan pada total aset yang dimiliki Bank Kalteng terus meningkat setiap tahunnya yang menandakkan bahwa kinerja yang dimiliki bank kalteng dapat dinilai baik secara kasat mata, akan tetapi masalah yang muncul adalah apakah Bank Kalteng merupakan bank yang sehat jika di nilai dengan analisis CAMEL? Apakah kesehatannya sesuai dengan kondisi keuangan yang digambarkan di atas atau tidak?

Penelitian ini penting untuk dilakukan untuk melihat tingkat kesehatan Bank Kalteng, dikarenakan Bank Kalteng sebagai bank daerah Kalimantan Tengah harus terkategorikan sebagai bank yang sehat guna terciptanya kepercayaan masyarakat serta dapat meningkatkan kondisi perekonomian di Kalimantan Tengah. Untuk mengukur tingkat kesehatan bank, metode CAMEL merupakan metode yang sesuai.

Berdasarkan latar belakang yang telah dikemukakan sebelumnya, maka penulis merumuskan permasalah dalam penelitian sebagai berikut: (1) Bagaimana tingkat kesehatan PT Bank Kalteng ditinjau dari rasio Capital? (2) Bagaimana tingkat kesehatan PT Bank Kalteng ditinjau dari rasio Assets Quality?(3) Bagaimana tingkat kesehatan PT Bank Kalteng 
ditinjau dari rasio Management?(4). Bagaimana tingkat kesehatan PT Bank Kalteng ditinjau dari rasio Earnings? (5). Bagaimana tingkat kesehatan PT Bank Kalteng ditinjau dari rasio Liquidity? (6). Bagaimana tingkat kesehatan PT Bank Kalteng ditinjau dengan metode CAMEL?

Adapun tujuan dari penelitian ini adalah sebagai berikut: (1). Untuk mengetahui tingkat kesehatan PT Bank Kalteng ditinjau dari rasio Capital. (2). Untuk mengetahui tingkat kesehatan PT Bank Kalteng ditinjau dari rasio Assets Quality. (3).Untuk mengetahui tingkat kesehatan PT Bank Kalteng ditinjau dari rasio Management. (4).Untuk mengetahui tingkat kesehatan PT Bank Kalteng ditinjau dari rasio Earnings. (5). Untuk mengetahui tingkat kesehatan PT Bank Kalteng ditinjau dari rasio Liquidity. (6). Untuk mengetahui tingkat kesehatan PT Bank Kalteng ditinjau dengan metode CAMEL

Adapun manfaat penelitian ini diharapkan bermanfaat untuk memperkaya ilmu pengetahuan dalam bidang manajemen keuangan, terutama dalam hal analisis laporan keuangan untuk menilai tingkat kesehatan keuangan pada PT Bank Kalteng. Bagi bank, hasil penelitian ini diharapkan dapat memberikan informasi kepada manajemen dan sebagai bahan pertimbangan dalam pengambilan keputusan serta kebijakan yang akan di ambil untuk mengembangkan bisnis usaha perbankan yang bersangkutan. Bagi Penulis untuk menerapkan teori yang telah dipelajari di bangku kuliah ke dalam praktik yang sesungguhnya dan tentunya penulis dapat memeroleh wawasan, ilmu, dan pengetahuan yang berhubungan dengan tingkat kesehatan bank. Bagi pihak luar, sebagai bahan masukan dan acuan dalam rangka membuat karya ilmiah berikutnya..

\section{Kajian Pustaka \\ Pengertian Bank}

Menurut UU No. 10 tahun 1998 tentang perbankan: Bank adalah badan usaha yang menghimpun dana dari masyarakat dalam bentuk simpanan dan juga menyalurkannya kepada masyarakat dalam bentuk kredit atau juga bentuk-bentuk lainnya dalam rangka untuk meningkatkan taraf hidup masyarakat banyak. Sedangkan perbankan merupakan segala sesuatu yang menyangkut tentang bank, mencakup kelembagaan, kegiatan usaha, serta cara dan proses dalam melaksanakan kegiatan usahanya

\section{Laporan Keuangan}

Menurut (Riyanto, 2012), Laporan keuangan yakni memberikan usaha mengenai keadaan finansial suatu perusahaan, yang mana Neraca (Balance Sheets) menyatakan nilai aktiva, utang serta modal sendiri pada waktu-waktu tertentu dan laporan rugi dan laba (income statement) menyatakan hasil-hasil yang telah dicapai selama periode tertentu, umumnya meliputi periode satu tahun.

\section{Tingkat Kesehatan Bank}

Menurut (Peraturan Bank Indonesia, 2004), Tingkat Kesehatan Bank merupakan hasil penilaian kualitatif atas berbagai aspek yang berpengaruh terhadap kondisi atau kinerja suatu Bank melalui penilaian faktor permodalan, kualitas aset, manajemen, rentabilitas, dan likuiditas. Penilaian terhadap faktor-faktor tersebut dilakukan melalui penilaian kuantitatif dan atau kualitatif setelah mempertimbangkan unsur judgement yang didasarkan atas materialitas dan signifikansi dari faktor-faktor penilaian serta pengaruh dari faktor lainnya seperti kondisi industri perbankan dan perekonomian nasional.

\section{Analisis Tingkat Kesehatan Bank Metode CAMEL}

Perusahaan yang bergerak di sektor perbankan memiliki karateristik bisnis yang cukup 
berbeda jika dibandingkan dengan perusahaan lainnya, sehingga terdapat rasio khusus untuk menilai kinerja fundamentalnya. Menurut Kasmir (dalam Hanafi dan Syam, 2019), CAMEL merupakan salah satu alat analisis perhitungan laporan keuangan sebuah bank yang ditetapkan oleh Bank Indonesia untuk mengukur tingkat kesehatan bank dari berbagai aspek yang berpengaruh pada perkembangan bank di masa yang akan datang.

Gambar 1. Kerangka Berpikir

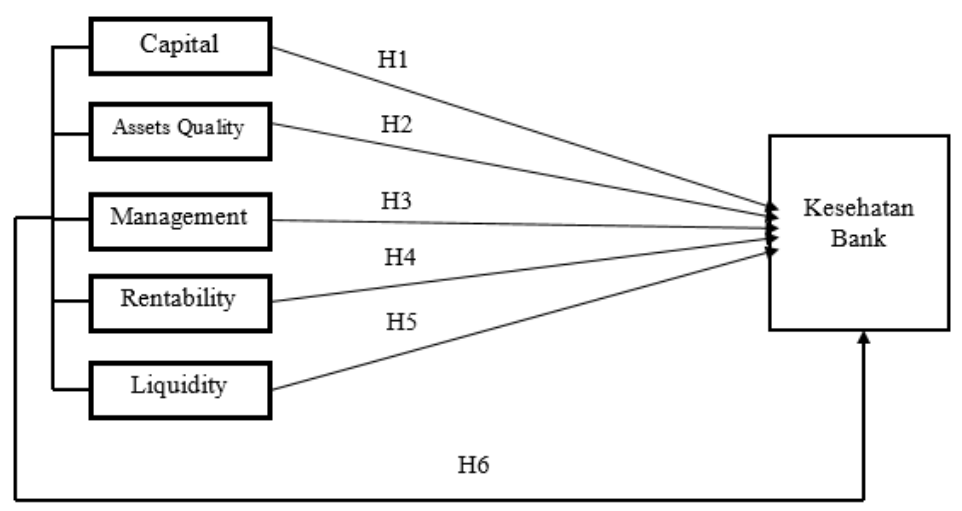

\section{Hipotesis Penelitian}

Menurut Sugiyono (2015) menyatakan bahwa hipotesis merupakan jawaban sementara terhadap masalah penelitian, dimana rumusan masalah dinyatakan dalam bentuk kalimat pertanyaan. Hipotesis pada penelitian ini adalah sebagai berikut :

H1 : Tingkat Kesehatan PT Bank Kalteng ditinjau dari aspek Capital adalah sehat.

H2 : Tingkat Kesehatan PT Bank Kalteng ditinjau dari aspek Assets quality adalah sehat.

H3 : Tingkat Kesehatan PT Bank Kalteng ditinjau dari aspek Management adalah sehat.

H4 : Tingkat Kesehatan PT Bank Kalteng ditinjau dari aspek Earnings adalah sehat.

H5 : Tingkat Kesehatan PT Bank Kalteng ditinjau dari aspek Liquidity adalah sehat.

H6 : Tingkat kesehatan PT Bank Kalteng dianalisis dengan metode CAMEL adalah sehat.

\section{Metode Penelitian}

Penelitian berlokasi di PT Bank Pembangunan Daerah Kalimantan Tengah semula berbentuk Perusahaan Daerah (PD), didirikan pada tanggal 28 Oktober 1961 dengan Akta Notaris Njoo Sio Liep Nomor 24 dengan nama PT BPD Kalimantan Tengah. Data pada objek penelitian yakni PT Bank Kalteng dengan melihat pada laporan publikasi keuangan periode 2016 - 2019 yang tersedia di situs resmi PT Bank Kalteng yaitu www.bankkalteng.co.id.

Ruang lingkup penelitian ini adalah penelitian dengan pendekatan kuantitatif. Metode penelitian yang digunakan dalam penelitian ini adalah menggunakan analisis rasio CAMEL bertujuan untuk mengetahui bagaimana tingkat kesehatan PT Bank Kalteng ditinjau dengan metode CAMEL.

\section{Metode Analisis Data}

Metode analisis yang digunakan dalam penelitian ini rumusnya adalah analisis CAMEL menurut (Surat Edaran Bank Indonesia Nomor : 6/23/DPNP tanggal 31 Mei, 2004) sebagai berikut :

a. Aspek Permodalan (Capital)

Rumusnya sebagai berikut : 
Capital Adequacy Ratio $=\frac{\text { Modal }}{\text { Aktiva Tertimbang Menurut Risiko }} \times 100 \%$

Nilai kredit dihitung sebagai berikut :

Untuk CAR $=0 \%$ atau negatif, maka nilai kredit $=0$, dan untuk setiap kenaikan $0,1 \%$, nilai kredit di tambah 1 dengan maksimum 100.

Rumus Nilai Kredit CAR : $\frac{C A R}{0,1}+1$

b. Aspek Kualitas Aktiva (Asset)

Rumusnya sebagai berikut :

Kualitas Aktiva Produktif $=\frac{\text { Aktiva Produktif yang Diklasifikasikan }}{\text { Totsl Aktiva Produktif }} \times 100 \%$

Aktiva produktif yang diklasifikasikan dapat dihitung dengan ketentuan sebagai berikut

1) $0 \%$ dari kredit lancar.

2) $25 \%$ dari kredit dalam perhatian khusus.

3) $50 \%$ dari kredit kurang lancar.

4) $75 \%$ dari kredit yang diragukan.

5) $100 \%$ dari kredit macet.

Nilai kredit rasio aktiva produktif yang di klasifikasikan dihitung sebagai berikut :

1. Nilai rasio $15,5 \%$ atau lebih nilai kreditnya $=0$

2. Setiap penurunan $0,15 \%$ dimulai dari $15,5 \%$ nilai ditambah 1 sampai maksimal 100.

c. Aspek Manajemen (Management)

Rumus Nilai Kredit KAP : $1+\frac{15,5-\text { Rasio KAP }}{0,15}$

Rumusnya sebagai berikut :

Net Profit Margin $=\frac{\text { Laba Bersih }}{\text { Pendapatan Operasional }} \times 100 \%$

Untuk mengetahui nilai kredit rasio NPM adalah sama nilainya dengan Rasio

NPM itu sendiri dengan nilai maksimum 100.

d. Aspek Rentabilitas (Earning)

1) ROA (Return On Asset)

Rumusnya sebagai berikut :

$$
\text { Return On Assets }=\frac{\text { Laba Sebelum Pajak }}{\text { Total Aktiva }} \times 100 \%
$$

Perhitungan nilai kredit ROA dilakukan sebagai berikut :

1. Untuk ROA sebesar $100 \%$ atau lebih, nilai kredit $=0$

2. Untuk setiap kenaikan $0,015 \%$, nilai kredit ditambah 1 dengan max. 100

$$
\text { Rumus Nilai Kredit ROA yaitu : } \frac{\text { Rasio ROA }}{0,015}
$$

2) BOPO (Beban Operasional terhadap Pendapatan Operasional)

Rumusnya sebagai berikut :

$$
\mathrm{BOPO}=\frac{\text { Biaya Operasional }}{\text { Pendapatan Operasional }} \times 100 \%
$$

Perhitungan nilai kredit BOPO dilakukan sebagai berikut:

1. Rasio $100 \%$ atau lebih, nilai kredit $=0$ 
e. Aspek Likuiditas (Liquidity)

2. Setiap penurunan sebesar $0,08 \%$, nilai kredit di tambah 1 , max. 100 .

$$
\text { Rumus Nilai Kredit BOPO }=\frac{100 \%-\text { Rasio BOPO }}{0,08}
$$

Rumusnya sebagai berikut :

$$
\mathrm{LDR}=\frac{\text { Kredit } \text { yang Diberikan }}{\text { Dane Pihak Ketiga }} \times 100 \%
$$

Perhitungan nilai kredit pada rasio LDR sebagai berikut :

1. Rasio LDR sebesar 110 atau lebih maka nilai kredit $=0$

$$
\text { Rumus nilai kredit LDR }=1+\frac{(115-\text { Rasio LDR }) \%}{1 \%} \times 4
$$

Setelah seluruh nilai diatas diperoleh, langkah selanjutnya adalah melakukan perhitungan dengan formula tingkat kesehatan bank analisis CAMEL sebagai berikut :

Tabel 2. Penilaian

\begin{tabular}{|c|c|c|}
\hline $\begin{array}{l}\text { Faktor } \\
\text { CAMEL }\end{array}$ & Rasio Yang dinilai & $\begin{array}{l}\text { Bobot Bank } \\
\text { Umum }\end{array}$ \\
\hline Capital & Kecukupan Modal (CAR) & $25 \%$ \\
\hline Assets Quality & Kulaitas Akiva Produktif & $30 \%$ \\
\hline Manajement & NPM & $25 \%$ \\
\hline Earnings & ROA dan BOPO & $10 \%$ \\
\hline Liquidity & LDR & $10 \%$ \\
\hline
\end{tabular}
Kesehatan Bank dengan Metode CAMEL

Penggolongan kategori tingkat kesehatan bank dibagi dalam empat kategori yaitu : sehat, cukup sehat, kurang sehat dan tidak sehat, namun sistem pemberian nilai dalam menetapkan tingkat kesehatan bank didasarkan pada "reward system" dengan nilai kredit antara 0 sampai dengan 100, yakni sebagai berikut :

Tabel 3. Nilai Kredit Penggolongan Tingkat Kesehatan Bank

\begin{tabular}{|c|l|}
\hline Nilai Kredit CAMEL & \multicolumn{1}{c|}{ Predikat } \\
\hline $81-100$ & Sehat \\
\hline $66-81$ & Cukup Sehat \\
\hline $51-66$ & Kurang Sehat \\
\hline $0-51$ & Tidak Sehat \\
\hline
\end{tabular}

Sumber : Surat Edaran Bank Indonesia Nomor : 6/23/DPNP tanggal 31 Mei 2004

\section{Hasil Penelitian Dan Pembahasan}

Analisis Data dan Hasil Penelitian

Faktor Permodalan (Capital)

Rasio permodalan diukur dengan membandingkan antara rasio Modal dengan Aktiva Tertimbang Menurut Risiko (ATMR), Sehingga berdasarkan rumus yang ada maka CAR (Capital Adequacy Ratio) Bank Kalteng selama tahun 2016 - 2019 adalah sebagai berikut : 
Tabel 4. Perhitungan Capital Adequacy Ratio (CAR)

\begin{tabular}{|c|c|c|r|}
\hline $\begin{array}{c}\text { Tahun } \\
(\mathbf{1})\end{array}$ & $\begin{array}{c}\text { Total Modal } \\
\text { (dalam jutaan } \\
\text { rupiah) } \\
\mathbf{( 2 )}\end{array}$ & $\begin{array}{c}\text { ATMR } \\
\text { (dalam jutaan } \\
\text { rupiah) } \\
\mathbf{( 3 )}\end{array}$ & $\begin{array}{c}\text { CAR } \\
\text { (\%) } \\
\mathbf{( 2 )}: \mathbf{( 3 ) * 1 0 0}\end{array}$ \\
\hline 2016 & 992.142 & 3.703 .628 & 26,79 \\
\hline 2017 & 1.386 .029 & 4.384 .000 & 31,62 \\
\hline 2018 & 1.489 .921 & 5.114 .652 & 29,13 \\
\hline 2019 & 1.512 .657 & 5.843 .602 & 25,89 \\
\hline
\end{tabular}

Sumber : Lampiran 6A

CAR Bank Kalteng per 31 Desember 2016 adalah sebesar 26,79\%, tahun 2017 sebesar $31,62 \%$, tahun 2018 sebesar 29,13\%, dan tahun 2019 sebesar 25,89\%. Terlihat bahwa terjadinya kenaikan yang signifikan dari tahun 2016 ke tahun 2017 lalu terjadinya penurunan di setiap tahun berikutnya. Terlepas dari itu, CAR pada Bank Kalteng melampaui ketentuan Kewajiban Pemenuhan Modal Minimum yang ditetapkan oleh Bank Indonesia yakni 8 \%.

Setelah nilai rasio CAR didapatkan, maka hal selanjutnya yang dilakukan adalah menghitung nilai kredit rasio CAR tersebut sebagai berikut :

Tabel 5. Nilai Kredit Rasio CAR

\begin{tabular}{|c|r|r|}
\hline Tahun & CAR (\%) & Nilai Kredit (\%) \\
\hline 2016 & 26,79 & 268,9 \\
\hline 2017 & 31,62 & 317,2 \\
\hline 2018 & 29,13 & 292,3 \\
\hline 2019 & 25,89 & 259,9 \\
\hline
\end{tabular}

Sumber : Lampiran 7A

Nilai Kredit CAR Bank Kalteng pada tahun 2016 sebesar 268,9, tahun 2017 sebesar 317,2 tahun 2018 sebesar 292,3 dan tahun 2019 sebesar 259,9. Maksimum nilai kredit adalah 100, maka pada tahun 2016 hingga tahun 2019 nilai kreditnya diakui sebesar 100.

Berdasarkan hasil perhitungan Faktor Permodalan pada tahun 2016 - 2019 menunjukan bahwa nilai kredit CAR melampaui nilai minimum yang ditetapkan oleh Bank Indonesia yakni 8\% maka rasio permodalan pada PT Bank Kalteng dikategorikan dalam kelompok SEHAT. Semakin tinggi nilai rasio CAR (Capital Adequacy Ratio) yang dimiliki bank maka akan semakin baik karena bank mampu menyediakan modal.

\section{Faktor Aset (Asset Quality)}

Tabel 6. Perhitungan KAP

\begin{tabular}{|c|c|c|r|}
\hline Tahun & $\begin{array}{c}\text { Aktiva Produktif yang } \\
\text { Diklasifikasikan } \\
\text { (dalam jutaan rupiah) } \\
(\mathbf{2})\end{array}$ & $\begin{array}{c}\text { Total Aktiva } \\
\text { Produktif } \\
\text { (dalam jutaan rupiah) } \\
\text { (3) }\end{array}$ & $\begin{array}{c}\text { KAP (\%) } \\
(\mathbf{2}):(\mathbf{3}) * \mathbf{1 0 0}\end{array}$ \\
\hline 2016 & 24.089 & 5.413 .743 & 0,44 \\
\hline 2017 & 25.796 & 5.763 .362 & 0,45 \\
\hline 2018 & 24.950 & 7.332 .027 & 0,34 \\
\hline 2019 & 30.299 & 8.594 .156 & 0,35 \\
\hline
\end{tabular}

Sumber : Lampiran 6B 
Berdasarkan data di atas, nilai KAP Bank Kalteng pada tahun 2016 adalah sebesar 0,44\%, tahun 2017 sebesar 0,45\%, tahun 2018 sebesar 0,34\%, dan tahun 2019 sebesar 0,35\%, secara keseluruhan kinerja bank kalteng dalam rasio KAP dinyatakan SEHAT karena semua angka rasio KAP setiap tahunnya berada di bawah 2\% menurut standar Bank Indonesia.

Setelah mendapatkan nilai rasionya, maka selanjutnya adalah melakukan perhitungan nilai kredit pada Kualitas Aktiva Produktif (KAP) pada PT Bank Kalteng 2016 - 2019.

Tabel 7. Nilai Kredit Rasio KAP

\begin{tabular}{|c|r|r|}
\hline Tahun & KAP (\%) & Nilai Kredit (\%) \\
\hline 2016 & 0,44 & 101,4 \\
\hline 2017 & 0,45 & 101,3 \\
\hline 2018 & 0,34 & 102,1 \\
\hline 2019 & 0,35 & 102,0 \\
\hline
\end{tabular}

Sumber : Lampiran 6B

Hasil dari perhitungan nilai kredit pada rasio KAP Bank Kalteng tahun 2016 - 2019 melewati nilai maksimum yaitu 100, sehingga semua nilai kredit rasio KAP dianggap 100.

\section{Faktor Manajemen (Management)}

Dalam menilai aspek manajemen biasanya dilakukan kuisioner yang ditujukan kepada pihak manajemen bank, tetapi hal itu sulit untuk dilakukan mengingat bahwa hal tersebut terkait dengan kerahasiaan perusahaan. Oleh sebab itu dalam pembahasan penelitian ini faktor manajemen diproyeksikan dengan rasio net profit margin (NPM) dapat dihitung dengan membandingkan antara laba bersih terhadap pendapatan operasionalnya. Sehingga berdasarkan rumus yang ada maka NPM (Net Profit Margin) Bank Kalteng selama tahun 2016 -2019 adalah sebagai berikut :

\begin{tabular}{l|c|c|r|r|}
\cline { 2 - 5 } & $\begin{array}{c}\text { Tahun } \\
\text { (1) }\end{array}$ & $\begin{array}{c}\text { Laba Bersih } \\
\text { (dalam jutaan rupiah) } \\
\text { (2) }\end{array}$ & $\begin{array}{c}\text { Pendapatan Operasional } \\
\text { (dalam jutaan rupiah) } \\
\text { (3) }\end{array}$ & $\begin{array}{c}\text { NPM (\%) } \\
\text { (2) / (3) * 100 }\end{array}$ \\
\cline { 2 - 5 } & 2016 & 190.245 & 40.225 & 472,95 \\
\cline { 2 - 5 } & 2017 & 208.025 & 42.572 & 488,64 \\
\cline { 2 - 5 } $\begin{array}{l}\text { Tabel 8. Perhitungan } \\
\text { Net Profit Margin } \\
\text { (NPM) }\end{array}$ & 2018 & 226.980 & 60.912 & 372,64 \\
\cline { 2 - 5 } & 2019 & 207.374 & 75.064 & 276,26 \\
\hline
\end{tabular}

Sumber : Lampiran 6C

Berdasarkan tabel diatas, Bank Kalteng mampu menghasilkan laba bersih yang cukup baik dilihat terus meningkat pada tahun 2016 - 2018 meskipun terjadi sedikit penurunan laba pada tahun 2019. Sedangkan pada pendapatan operasionalnya kerap mengalami kenaikan yang pasti dari tahun ke tahun. Jikalau dilihat dari sisi rasio, sempat mengalami kenaikan pada tahun 2017 dan menurun kembali hingga tahun 2019.

Setelah nilai rasio NPM didapatkan, maka hal selanjutnya yang dilakukan adalah menghitung nilai kredit rasio NPM, tetapi karena aspek manajemen diproyeksikan dengan net profit margin maka nilai rasio yang diperoleh langsung menjadi nilai kredit dari rasio NPM dengan nilai maksimum 100 sebagai berikut : 
Tabel 9. Nilai Kredit Rasio NPM

\begin{tabular}{|c|r|r|}
\hline Tahun & NPM (\%) & Nilai Kredit (\%) \\
\hline 2016 & 472,95 & 472,95 \\
\hline 2017 & 488,64 & 488,64 \\
\hline 2018 & 372,64 & 372,64 \\
\hline 2019 & 276,26 & 276,26 \\
\hline
\end{tabular}

Sumber : Lampiran 7C

Berdasarkan hasil perhitungan di atas, rasio Net Profit Margin Bank Kalteng pada tahun 2016-2019 menunjukan nilai kredit NPM melebihi angka 100.

\section{Faktor Rentabilitas (Earnings)}

Faktor Rentabilitas menurut (Munawir, 2010), rentabilitas adalah kemampuan perusahaan dalam menghasilkan laba selama periode tertentu. Dalam mengukur faktor rentabilitas perlu mengetahui nilai 2 rasio yakni rasio ROA (Return On Asset) dan Rasio BOPO (Beban Operasional Pendapatan Operasional).

ROA menurut (Hanafi, 2016) merupakan kemapuan perusahaan dalam menghasilkan keuntungan berdasarkan tingkat aktiva tertentu. Hasil nilai rasio ROA diperoleh dari hasil pembagian antara Laba sebelum pajak perusahaan terhadap total asset yang dimiliki perusahaan. Berikut adalah hasil dari perhitungan Return on Assets (ROA) pada Bank Kalteng:

Tabel 10. Perhitungan Return On Assets (ROA)

\begin{tabular}{|c|r|r|r|}
\hline $\begin{array}{c}\text { Tahun } \\
(\mathbf{1})\end{array}$ & $\begin{array}{c}\text { Laba Sebelum Pajak } \\
\text { (dalam jutaan rupiah) } \\
\text { (2) }\end{array}$ & $\begin{array}{c}\text { Total Aset } \\
\text { (dalam jutaan rupiah) } \\
\mathbf{( 3 )}\end{array}$ & $\begin{array}{c}\text { ROA (\%) } \\
\mathbf{( 2 )} /(\mathbf{3}) * \mathbf{1 0 0}\end{array}$ \\
\hline 2016 & 263.112 & 5.858 .589 & 4,24 \\
\hline 2017 & 283.716 & 6.226 .933 & 3,84 \\
\hline 2018 & 306.347 & 7.876 .078 & 3,87 \\
\hline 2019 & 294.040 & 9.065 .881 & 3,24 \\
\hline
\end{tabular}

Sumber : Lampiran 6D

Berdasarkan hasil perhitungan tabel di atas bahwa ROA Bank Kalteng per 31 Desember 2016 sebesar 4,24\%, 2017 sebesar 3,84\%, 2018 sebesar 3,87\% dan 2019 sebesar 3,24\%. Terlihat bahwa dari tahun 2016 -2019 mengalami penurunan angka, menandakan bahwa pengelolaan asset bank kalteng dalam menghasilkan laba mengalami sedikit penurunan tetapi tetap melampaui kriteria maksimum yang di tetapkan Bank Indonesia yakni di atas angka $1,5 \%$.

Setelah mendapatkan nilai rasio ROA maka selanjutnya adalah melakukan perhitungan nilai kredit pada Return On Assets (ROA) pada PT Bank Kalteng 2016-2019.

Tabel 11. Nilai Kredit Rasio ROA

\begin{tabular}{|c|r|r|}
\hline Tahun & \multicolumn{1}{|c|}{ ROA (\%) } & \multicolumn{1}{c|}{ Nilai Kredit (\%) } \\
\hline 2016 & 4,24 & 282,7 \\
\hline 2017 & 3,84 & 256,0 \\
\hline 2018 & 3,87 & 258,0 \\
\hline 2019 & 3,24 & 216,0 \\
\hline
\end{tabular}

Sumber : Lampiran 7D 
Nilai Kredit pada rasio ROA Bank Kalteng per 31 Desember 2016 sebesar 282,7, tahun 2017 sebesar 256, tahun 2018 sebesar 258, dan tahun 2019 sebesar 211,3. Walaupun lihat nilai ROA yang menurun dari tahun ke tahun tetapi Secara keseluruhan nilai ROA Bank Kalteng tersebut selalu melampaui nilai maksimum yaitu 100.

Selanjutnya rasio Beban Operasional Pendapatan Operasional (BOPO), sesuai namanya BOPO adalah perbandingan antara beban operasional terhadap pendapatan operasional suatu perusahaan. Digunakan untuk mengukur efisiensi bank dalam mengendalikan biaya operasional terhadap pendapatan operasionalnya. Berikut adalah nilai Beban Operasional Pendapatan Operasional (BOPO) pada bank Kalteng tahun 2016-2019).

Tabel 12. Perhitungan BOPO

\begin{tabular}{|c|c|c|r|}
\hline Tahun & $\begin{array}{c}\text { Beban } \\
\text { Operasional } \\
\text { (dalam jutaan } \\
\text { rupiah) } \\
\text { (2) }\end{array}$ & $\begin{array}{c}\text { Pendapatan } \\
\text { Operasional } \\
\text { (dalam jutaan } \\
\text { rupiah) } \\
\mathbf{( 3 )}\end{array}$ & $\begin{array}{c}\text { BOPO (\%) } \\
\mathbf{( 2 )} /(\mathbf{3}) * 100\end{array}$ \\
\hline 2016 & 328.491 & 40.225 & 64,06 \\
\hline 2017 & 360.806 & 42.572 & 70,94 \\
\hline 2018 & 385.647 & 60.912 & 71,15 \\
\hline 2019 & 440.288 & 75.064 & 72,94 \\
\hline
\end{tabular}

Sumber : Lampiran 6E

Berdasarkan perhitungan nilai di atas, rasio BOPO pada Bank Kalteng tahun 2016 sebesar 64,06\%, tahun 2017 sebesar 70,94\%, tahun 2018 sebesar 71,15\%, dan tahun 2019 sebesar $72,94 \%$. Secara kasat mata terjadinya peningkatan setiap tahunnya pada nilai rasio BOPO, hal ini menunjukan semakin turunnya kinerja usaha Bank Kalteng. Tetapi Secara teknis Kinerja BOPO Bank Kalteng mendapat predikat SEHAT secara keseluruhan dikarenakan nilai setiap tahunnya berada pada angka di bawah 94\% dimana semakin kecil angka rasio BOPO maka kinerjanya semakin baik sesuai ketentuan Bank Indonesia.

Setelah mendapatkan nilai rasionya, maka selanjutnya adalah melakukan perhitungan nilai kredit pada Beban Operasional pada Pendapatan Operasional (BOPO) pada PT Bank Kalteng 2016-2019.

Tabel 13. Nilai Kredit Rasio BOPO

\begin{tabular}{|l|r|r|}
\hline Tahun & BOPO (\%) & Nilai Kredit (\%) \\
\hline 2016 & 64,06 & 449,25 \\
\hline 2017 & 70,94 & 363,25 \\
\hline 2018 & 71,15 & 360,63 \\
\hline 2019 & 72,94 & 338,25 \\
\hline
\end{tabular}

Sumber : Lampiran 7E

Nilai Kredit pada rasio BOPO Bank Kalteng per 31 Desember 2016 sebesar 449,25, tahun 2017 sebesar 363,25, tahun 2018 sebesar 360,625, dan tahun 2019 sebesar 338,25. Nilai kredit BOPO lebih besar daripada kriteria tingkat kesehatan bank yang ditetapkan Bank Indonesia yaitu maksimum 100 . 


\section{Faktor Likuiditas (Liquidity)}

Liquidity (likuiditas), rasio yang digunakan adalah LDR (Loan to deposit ratio) yaitu rasio kredit yang di berikan membandingkan dengan dana yang diterima olek pihak ketiga. Berikut adalah hasil dari perhitungan Loan to Deposit Ratio (LDR) pada Bank Kalteng tahun 20162019) :

Tabel 14. Perhitungan LDR

\begin{tabular}{|c|c|c|r|}
\hline $\begin{array}{c}\text { Tahun } \\
\mathbf{( 1 )}\end{array}$ & $\begin{array}{c}\text { Kredit } \\
\text { diberikan } \\
\text { (dalam jutaan } \\
\text { rupiah) } \\
\mathbf{( 2 )}\end{array}$ & $\begin{array}{c}\text { Dana Pihak } \\
\text { Ketiga } \\
\text { (dalam jutaan } \\
\text { rupiah) } \\
\mathbf{( 3 )}\end{array}$ & $\begin{array}{c}\text { LDR (\%) } \\
\mathbf{( 2 ) / ( 3 ) * 1 0 0}\end{array}$ \\
\hline 2016 & 4.074 .752 & 4.089 .942 & 99,63 \\
\hline 2017 & 4.504 .944 & 4.658 .360 & 96,71 \\
\hline 2018 & 5.207 .681 & 6.105 .106 & 85,30 \\
\hline 2019 & 6.055 .172 & 6.553 .196 & 92,40 \\
\hline
\end{tabular}

Sumber : Lampiran 6F

Berdasarkan perhitungan di atas, nilai rasio LDR pada Bank Kalteng tahun 2016 sebesar 99,63\%, tahun 2017 sebesar 96,63\%, tahun 2018 sebesar $85 \%$, dan tahun 2019 sebesar 92 \%. Hal ini menunjukan secara keseluruhan nilai rasio LDR Bank Kalteng berpredikat CUKUP SEHAT berdasarkan penggolongan kesehatan yang di tetapkan BI, jika nilai tersebut berada di antara $85 \%$ hingga $100 \%$.

Setelah mendapatkan nilai rasionya, hal selanjutnya adalah melakukan perhitungan nilai kredit pada rasio Load to Deposit Ratio (LDR) pada PT Bank Kalteng 2016-2019.

Tabel 15. Nilai Kredit Rasio LDR

\begin{tabular}{|c|r|r|}
\hline Tahun & LDR (\%) & Nilai Kredit (\%) \\
\hline 2016 & 99,63 & 62,48 \\
\hline 2017 & 96,71 & 74,16 \\
\hline 2018 & 85,30 & 119,80 \\
\hline 2019 & 92,40 & 91,40 \\
\hline
\end{tabular}

Sumber : Lampiran 7F

\section{Hasil Tingkat Kesehatan PT Bank Kalteng}

Tabel 16. Nilai Bersih Rasio CAMEL Tahun 2016

\begin{tabular}{|l|l|c|r|r|r|r|r|}
\hline Tahun & \multicolumn{1}{|c|}{$\begin{array}{c}\text { Faktor } \\
\text { Penilaian }\end{array}$} & $\begin{array}{c}\text { Indikator } \\
\text { Kerja }\end{array}$ & $\begin{array}{c}\text { Nilai } \\
\text { Rasio } \\
\mathbf{( \% )}\end{array}$ & $\begin{array}{c}\text { Nilai } \\
\text { Kredit } \\
\mathbf{( M a x} \\
\mathbf{1 0 0}\end{array}$ & $\begin{array}{c}\text { Bobot } \\
\mathbf{( \% )}\end{array}$ & Kondisi & $\begin{array}{c}\text { Nilai } \\
\text { CAMEL }\end{array}$ \\
\hline 2016 & Permodalan & CAR & 26,79 & 268,9 & 25 & SEHAT & 25,00 \\
\cline { 2 - 8 } & $\begin{array}{l}\text { Kualitas } \\
\text { Aktiva }\end{array}$ & KAP & 0,44 & 101,4 & 30 & SEHAT & 30,00 \\
\cline { 2 - 8 } & Manajemen & NPM & 472,9 & 473,0 & 25 & SEHAT & 25,00 \\
\cline { 2 - 8 } & Earnings & ROA & 4,24 & 282,7 & 5 & SEHAT & 5,00 \\
\hline
\end{tabular}


Tabel 17.

Nilai Bersih

Rasio

CAMEL

Tahun 2017

\begin{tabular}{|l|l|l|l|r|r|r|r|}
\hline & BOPO & 64,06 & 449,2 & 5 & SEHAT & 5,00 \\
\cline { 2 - 8 } & Likuiditas & LDR & 99,63 & 62,5 & 10 & $\begin{array}{r}\text { CUKUP } \\
\text { SEHAT }\end{array}$ & 6,25 \\
\hline \multicolumn{8}{|c|}{ Jumlah Nilai CAMEL } \\
\hline
\end{tabular}

Sumber : Data Olahan 2021

\begin{tabular}{|c|c|c|c|c|c|c|c|}
\hline Tahun & $\begin{array}{l}\text { Faktor } \\
\text { Penilaian }\end{array}$ & $\begin{array}{c}\text { Indikator } \\
\text { Kerja }\end{array}$ & $\begin{array}{c}\text { Nilai } \\
\text { Rasio } \\
(\%)\end{array}$ & $\begin{array}{c}\text { Nilai } \\
\text { Kredit } \\
\text { (Max } \\
\text { 100) }\end{array}$ & $\begin{array}{c}\text { Bobot } \\
(\%)\end{array}$ & Kondisi & $\begin{array}{l}\text { Nilai } \\
\text { CAMEL }\end{array}$ \\
\hline \multirow{6}{*}{2017} & Permodalan & CAR & 31,62 & 317,2 & 25 & SEHAT & 25,00 \\
\hline & $\begin{array}{l}\text { Kualitas } \\
\text { Aktiva }\end{array}$ & KAP & 0,45 & 101,3 & 30 & SEHAT & 30,00 \\
\hline & Manajemen & NPM & 488,64 & 488,6 & 25 & SEHAT & 25,00 \\
\hline & \multirow{2}{*}{ Earnings } & ROA & 3,84 & 256,0 & 5 & SEHAT & 5,00 \\
\hline & & ВOPO & 70,94 & 363,3 & 5 & SEHAT & 5,00 \\
\hline & Likuiditas & LDR & 96,71 & 74,2 & 10 & $\begin{array}{l}\text { CUKUP } \\
\text { SEHAT }\end{array}$ & 7,41 \\
\hline & & Jumlah & i CAN & & & & 97,41 \\
\hline
\end{tabular}

Sumber : Data Olahan 2021

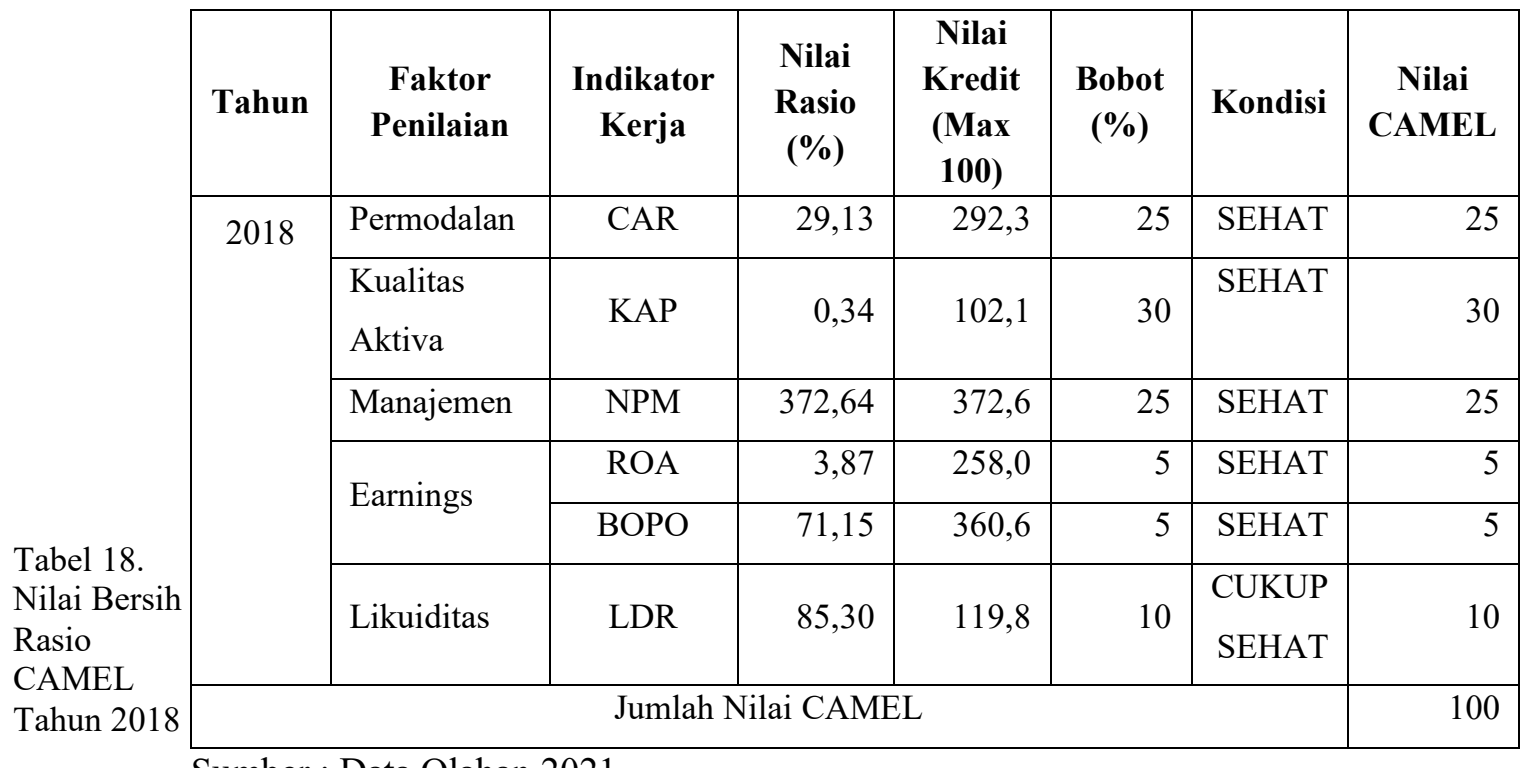

Sumber : Data Olahan 2021 
Tabel 19.

Nilai Bersih

Rasio

CAMEL

Tahun 2019

\begin{tabular}{|c|c|c|c|c|c|c|c|}
\hline Tahun & $\begin{array}{c}\text { Faktor } \\
\text { Penilaian }\end{array}$ & $\begin{array}{c}\text { Indikator } \\
\text { Kerja }\end{array}$ & $\begin{array}{c}\text { Nilai } \\
\text { Rasio } \\
(\%)\end{array}$ & $\begin{array}{c}\text { Nilai } \\
\text { Kredit } \\
\text { (Max } \\
\text { 100) }\end{array}$ & $\begin{array}{c}\text { Bobot } \\
(\%)\end{array}$ & Kondisi & $\begin{array}{c}\text { Nilai } \\
\text { CAMEL }\end{array}$ \\
\hline \multirow[t]{6}{*}{2019} & Permodalan & CAR & 25,89 & 259,9 & 25 & SEHAT & 25,00 \\
\hline & $\begin{array}{l}\text { Kualitas } \\
\text { Aktiva }\end{array}$ & KAP & 0,35 & 102,0 & 30 & SEHAT & 30,00 \\
\hline & Manajemen & NPM & 276,26 & 276,3 & 25 & SEHAT & 25,00 \\
\hline & \multirow{2}{*}{ Earnings } & $\mathrm{ROA}$ & 3,17 & 216,0 & 5 & SEHAT & 5,00 \\
\hline & & BOPO & 72,94 & 338,3 & 5 & SEHAT & 5,00 \\
\hline & Likuiditas & LDR & 92,40 & 91,4 & 10 & $\begin{array}{l}\text { CUKUP } \\
\text { SEHAT }\end{array}$ & 9,14 \\
\hline \multicolumn{7}{|c|}{ Jumlah Nilai CAMEL } & 99,14 \\
\hline
\end{tabular}

Sumber : Data Olahan 2021

Berdasarkan pada hasil perhitungan yang tertera di atas, maka dapat ditentukan tingkat kesehatan PT Bank Kalteng yang tersajikan dalam tabel di bawah ini :

Tabel 20. Tingkat Kesehatan Bank Kalteng

\begin{tabular}{|c|r|c|}
\hline Tahun & Nilai CAMEL & Tingkat Kesehatan Bank \\
\hline 2016 & 96,25 & SEHAT \\
\hline 2017 & 97,41 & SEHAT \\
\hline 2018 & 100,00 & SEHAT \\
\hline 2019 & 99,14 & SEHAT \\
\hline
\end{tabular}

Sumber : Data Diolah 2021

\section{Analisis Deskriptif Tingkat Kesehatan PT Bank Kalteng Periode 2016-2019 Dengan Menggunakan Metode CAMEL}

Analisis Rasio CAMEL terdiri dari: Capital dengan rasio CAR, Asset dengan rasio KAP, Management dengan rasio NPM, Earning dengan rasio ROA dan BOPO, dan Liquidity dengan rasio LDR. Penjelasannya rasio CAMEL akan dijabarkan dengan cara per rasio dan per tahun.

Rasio CAMEL pada Capital (CAR) yang dimiliki PT Bank Kalteng tahun 2016 sebesar 26,79\% dengan total modal Rp 992.142 dan ATMR Rp 3.703.628, tahun 2017 sebesar 31,62\% dengan total modal Rp 1.386.029 dan ATMR Rp 4.384.000 , tahun 2018 sebesar 29,13\% dengan total modal Rp 1.489.921 dan ATMR Rp 5.114.652, dan tahun 2019 sebesar 25,89\% dengan total modal Rp 1.512.657 dan ATMR Rp 5.843.602.

Semakin tinggi rasio CAR maka semakin baik pada mencukupi kapital pada menutup Aktiva tertimbang menurut risiko (ATMR) \& kebalikannya semakin rendah rasio CAR maka semakin tidak baik pada mencukupi kapital pada menutup resiko ATMR nya. Rasio CAR pada tahun 2016, 2017, 2018, 2019 secara keseluruhan berada di atas 8\% sehingga menandakan bahwa rasio CAR pada Bank Kalteng terkategorikan SEHAT, serta nilai rasio CAR tertinggi ada pada tahun 2017 sebesar 31,62\%. 
Rasio CAMEL pada Assets Quality (KAP) yang dimiliki PT Bank Kalteng tahun 2016 sebesar $0,44 \%, 2017$ sebesar 0,45\%, 2018 sebesar 0,34\% dan 2019 sebesar 0,35\%. Semakin kecil nilai KAP maka akan semakin baik karena aktiva produktif bermasalah pada Bank Kalteng kecil. Jikalau nilai rasio KAP dibawah 2\% maka kualitas aktiva tersebut sangat baik dan setiap tahun rasio KAP Bank Kalteng selalu di bawah 2\% yang menandakan bahwa KAP pada Bank Kalteng adalah SEHAT. Dan nilai rasio KAP tersehat adalah pada tahun 2018 sebesar $0,34 \%$.

Rasio CAMEL pada Management (NPM) yang dimiliki PT Bank Kalteng adalah dengan membandingkan laba bersih dengan pendapatan operasionalnya sehingga pada tahun 2016 sebesar 472,95\% dengan laba bersih Rp 190.245 dan pendapatan operasional Rp 40.225, tahun 2017 sebesar 488,64\% dengan laba bersih Rp 208.025 dan pendapatan operasional $\mathrm{Rp}$ 42.572, tahun 2018 sebesar 372,64\% dengan laba bersih $\mathrm{Rp} 226.980$ dan pendapatan operasional Rp 60.912, tahun 2019 sebesar 276,26 dengan laba bersih Rp 207.374 dan pendapatan operasional Rp 75.064 .

Semakin tinggi nilai rasio NPM maka semakin baik dalam menghasilkan laba bersih berdasarkan pendapata operasional dan sebaliknya semakin rendah rasio NPM maka semakin buruk dalam menghasilkan laba bersih dari pendapatan operasionalnya.Secara keseluruhan tahun, nilai rasio NPM selalu melewati angka 100 menandakan bahwa setiap tahunnya nilai NPM Bank Kalteng dalam keadaan yang SEHAT dan nilai rasio NPM tertinggi ada pada tahun 2017 sebesar 488,64\%.

Rasio CAMEL Earnings atau Profitabilitas yang terdiri dari dua rasio yakni rasio ROA dan BOPO. Rasio ROA yang dimiliki PT Bank Kalteng pada tahun 2016 sebesar 4,24\% dengan laba sebelum pajak Rp 265.166 dan total aset $\mathrm{Rp} 5.858 .589$, tahun 2017 sebesar 3,84\% dengan laba sebelum pajak Rp 283.716 dan total aset $R p$ 6.226.933, tahun 2018 sebesar 3,87\% dengan laba sebelum pajak Rp 306.347 dan total aset Rp 7.876.078, tahun 2019 sebesar 3,17\% dengan laba sebelum pajak Rp 294.040 dan total aset Rp 9.065.881.

Penilaian nilai ROA adalah kemampuan bank dalam menghasilkan laba yang diperoleh bila diukur dari total asetnya. Semakin tinggi nilai ROA semakin baik keuntungan yang bisa dicapai oleh bank. Rasio ROA yang dimiliki oleh bank Kalteng setiap tahunnya selalu melebihi angka 1,5\% yang menandakan nilai ROA berpredikat SEHAT dan nilai rasio ROA tertinggi ada pada tahun 2016 sebesar 4,24\%.

Sedangkan pada Rasio BOPO yang dimiliki PT Bank Kalteng pada tahun 2016 sebesar 64,06\%, tahun 2017 sebesar 70,94\%, tahun 2018 sebesar 71,15\% dan tahun 2019 sebesar $72,94 \%$, menandakan semua nilai rasio BOPO di setiap tahu berada di bawah $94 \%$ yang berarti BOPO Bank Kalteng terkategorikan SEHAT. Penilaian nilai rasio BOPO adalah dengan membandingkan beban operasional terhadap pendapatan operasional. Semakin tinggi nilai BOPO maka semakin buruk kemampuan bank dalam mengelola beban operasional terhadap pendapatan operasional. Nilai Rasio BOPO selalu mengalami kenaikan pada tahun 2016 hingga ke tahun 2019, yang menandakan tahun 2016 merupakan tahun dengan BOPO tersehat karena semakin kecil nilai BOPO nya yakni sebesar 64,06\%.

Rasio CAMEL Liquidity (LDR) yang dimiliki PT Bank Kalteng pada tahun 2016 sebesar 99,63\%, tahun 2017 sebesar 96,71\%, tahun 2018 sebesar 85,30\% dan tahun 2019 sebesar $92,40 \%$. Penilaian nilai rasio LDR adalah kemampuan bank dalam menyalurkan dana pada masyarakat yang berasal dari pihak ketiga. Semakin rendah nilai rasio LDR maka akan semakin baik bank dalam menyalurkan dana dan sebaliknya. Rasio LDR yang dimiliki Bank Kalteng setiap tahunnya mengalami fluktuasi pada tahu 2016 hingga tahun 2018 dan naik 
kembali pada tahun 2019. Secara keseluruhan pada tahun 2016 - 2019 rasio LDR berpredikat CUKUP SEHAT karena nilainya berada antara $85 \%$ hingga $100 \%$.

Pada tahun 2016 Bank Kalteng menghasilkan nilai CAMEL sebesar 96,25 dan masuk dalam kategori (Sehat) didapat dari nilai rasio CAR sebesar 26,79\% yang sanggup mencukupi modal dalam menutup resiko dari dana pihak ketiga, nilai rasio KAP sebesar 0,44\% yang sanggup menekan masalah aktiva produktifnya, rasio NPM sebesar 472,95\% yang sanggup menghasilkan laba bersih terhadap laba operasionalnya, rasio ROA sebesar 4,24\% yaitu sanngup mengelola terhadap nilai total aset untuk menghasilkan laba sebelum pajak, nilai rasio BOPO sebesar $64,06 \%$ yang sanggup mengefisiensi beban operasional terhadap pendapatan operasionalnya, dan nilai rasio LDR sebesar 99,63\% yang sanggup memperlihatkan kemampuan bank dalam menyalurkan dana yang berasal dari dana pihak ketiga.

Lalu tahun 2017 Bank Kalteng menghasilkan nilai CAMEL sebesar 97,41 dan masuk dalam kategori (Sehat) didapat dari nilai rasio CAR sebesar 31,62\% yang sanggup mencukupi modal dalam menutup resiko dari dana pihak ketiga, nilai rasio KAP sebesar $0,45 \%$ yang sanggup menekan masalah aktiva produktifnya, rasio NPM sebesar 488,64\% yang sanggup menghasilkan laba bersih terhadap laba operasionalnya, rasio ROA sebesar 3,84\% yaitu sanggup mengelola terhadap nilai total aset untuk menghasilkan laba sebelum pajak, nilai rasio BOPO sebesar 70,94\% yang sanggup mengefisiensi beban operasional terhadap pendapatan operasionalnya, dan nilai rasio LDR sebesar 96,71\% yang sanggup memperlihatkan kemampuan bank dalam menyalurkan dana yang berasal dari dana pihak ketiga. Nilai CAMEL naik sebesar 1,16 pada tahun 2017. Kenaikan nilai CAMEL disebabkan oleh Nilai kredit rasio LDR yang mengalami kenaikan.

Lalu tahun 2018 Bank Kalteng menghasilkan nilai CAMEL sebesar 100 dan masuk dalam kategori (Sehat) didapat dari nilai rasio CAR sebesar 29,13\% yang sanggup mencukupi modal dalam menutup resiko dari dana pihak ketiga, nilai rasio KAP sebesar $0,34 \%$ yang sanggup menekan masalah pada aktiva produktifnya, rasio NPM sebesar 372,64\% yang sanggup menghasilkan laba bersih terhadap laba operasionalnya, rasio ROA sebesar 3,87\% yaitu sanggup mengelola terhadap nilai total aset untuk menghasilkan laba sebelum pajak, nilai rasio BOPO sebesar $71,15 \%$ yang sanggup mengefisiensi beban operasional terhadap pendapatan operasionalnya, dan nilai rasio LDR sebesar 85,30\% yang sanggup memperlihatkan kemampuan bank dalam menyalurkan dana yang berasal dari dana pihak ketiga. Nilai CAMEL naik sebesar 2,59 pada tahun 2018. Kenaikan nilai CAMEL disebabkan oleh semua nilai kredit yang memenuhi standar maksimum sehingga performa Bank Kalteng pada tahun 2018 sangat baik.

Pada tahun 2019 Bank Kalteng menghasilkan nilai CAMEL sebesar 99,14 dan masuk dalam kategori (Sehat) didapat dari nilai rasio CAR sebesar 25,89\% yang sanggup mencukupi modal dalam menutup resiko dari dana pihak ketiga, nilai rasio KAP sebesar 0,35\% yang sanggup menekan masalah aktiva produktifnya, rasio NPM sebesar $276,26 \%$ yang sanggup menghasilkan laba bersih terhadap laba operasionalnya, rasio ROA sebesar $3.17 \%$ yaitu sanggup mengelola terhadap nilai total aset untuk menghasilkan laba sebelum pajak, nilai rasio BOPO sebesar $72,94 \%$ yang sanggup mengefisiensi beban operasional terhadap pendapatan operasionalnya, dan nilai rasio LDR sebesar $92,40 \%$ yang sanggup memperlihatkan kemampuan bank dalam menyalurkan dana yang berasal dari dana pihak ketiga. Nilai CAMEL turun sebesar 0,86 pada tahun 2019. Meskipun terjadi penurunan pada 
akumulasi nilai kreditnya, Bank Kalteng tetap memeroleh predikat sehat dan tidak berpengaruh signifikan terhadap kesehatan dan kinerja Bank Kalteng.

Secara keseluruhan, tingkat kesehatan PT Bank Kalteng tahun 2016-2019 digolongkan sebagai bank yang Sehat. Karena Menurut standar Bank Indonesia, Bank yang sehat adalah bank yang memeroleh nilai akumulasi kreditnya berada di atas $80 \%$ dan ini membuktikan bahwa setiap tahunnya Bank Kalteng memiliki kinerja yang baik dalam pengelolaan yang dimilikinya jikalau diukur dengan perhitungan Rasio CAMEL..

\section{Kesimpulan}

Berdasarkan data yang didapat dari PT Bank Kalteng dan analisis data, dapat disimpulkan bahwa hasil akhir atau nilai kumulatif CAMEL pada penilaian tingkat kesehatan PT Bank Kalteng adalah sebagai berikut : Tahun 2016 nilainya sebesar 96,25 yakni tergolong sehat, pada tahun 2017 nilainya sebesar 97,41 yakni tergolong sehat, lalu tahun 2018 nilainya sebesar 100 yakni dimana tahun ini merupakan tahun yang mendapat nilai CAMEL tersehat, dan tahun 2019 nilainya sebesar 99,14 yakni tergolong sehat. Terlihat bahwa setiap tahunnya dimulai dari tahun 2016 nilai CAMEL selalu mengalami kenaikan, dan terjadi penurunan pada tahun 2019 tetapi tidak terlalu berpengaruh pada kinerja Bank Kalteng yang tetap terkategorikan Bank yang sehat.

Diharapkan kepada semua pihak yang terlibat dalam pengelolaan Bank Kalteng yang menjalankan tugasnya dengan baik agar tetap dan selalu mempertahankan dan meningkatkan kinerja keuangan Bank Kalteng, dikarenakan hampir semua rasio CAMEL telah mendapat predikat sehat maka saya hanya memberikan saran terhadap pengelolaan rasio LDR, Bank Kalteng perlu menaikkan dana pihak ketiga dengan mendobrak dana simpanan agar penyaluran pembiayaan lebih lancar.

Penelitian ini cukup terbatas karena hanya meneliti mengenai Bank Kalteng pada tahun 2016 higga tahun 2019, maka kepada para peneliti selanjutnya jika mengambil obyek bank yang sama agar rentang waktu penelitian yang lebih panjang guna memeroleh hasil penelitian yang lebih komprehensif serta memperluas penelitian untuk jenis bank yang berbeda.

\section{Daftar Pustaka}

Bambang, Riyanto. (2012). Dasar-dasar Pembelanjaan, Edisi 4, Yogyakarta:BPFE

Bank Indonesia (2004, 31 Mei). Surat Edaran Bank Indonesia No. 6/23/DPNP tanggal 31 Mei 2004, Perihal Sistem Penilaian Tingkat Kesehatan Bank Umum. Juni 5 2020.https://www.bi.go.id/id/archive/arsipperaturan/Documents/0151b17420f84d118d e8fdf0c0642730se623dpnp.pdf

Bank Indonesia (1998) Undang-Undang Republik Indonesia Nomor 7 Tahun 1992 Tentang Perbankan Sebagaimana Telah Diubah Dengan Undang-Undang Nomor 10 Tahun 1998. Juni 2020. 5, https://www.ojk.go.id/waspadainvestasi/id/regulasi/Documents/UU_Perbankan.pdf

Bank Kalteng. (2021). Laporan Keuangan Tahun 2016-2019. Januari 04, 2021. 
www.bankkalteng.co.id

Dendawijaya, Lukman. (2009). Manajemen Perbankan (edisi kedua). Jakarta: Ghalia Indonesia.

Fernando. (2017). Analisis Kinerja Keuangan Bank dengan Menggunakan metode CAMEL (Studi Kasus Pada PT Bank BPD DIY 2014-2016). Skripsi. Yogyakarta.

Hanafi, Muhammad Alam Nayrah dan Syam, Shofiana. (2019). Analisis Kinerja Keuangan Berdasarkan Prinsip CAMEL pada PT Bank Rakyat Indonesia (BRI) yang terdaftar di Bursa Efek Indonesia. PAY Jurnal Keuangan dan Perbankan. Vol.1 No. 1, hlm : 48-57. (e-ISSN 2657-0459 p-ISSN 2684-6713).

Harahap, Sofyan Syafri. (2011). Teori Akuntansi Edisi Revisi 2011. Jakarta: Rajawali Pers.

Kamal, Habibie. (2019). Analisis Tingkat Kesehatan Bank Dengan Metode CAMEL ( Studi pada PT Bank Aceh Syariah Periode 2016-2018). Skripsi, Banda Aceh

Kasmir. (2014), Bank Dan Lembaga Keuangan Lainnya. Ed. Revisi, Cetakan Keenambelas, Jakarta : PT. Raja Grafindo Persada.

Laporan Tahunan PT. Bank Kalteng tahun 2019.

Laporan Tahunan PT. Bank Kalteng tahun 2017.

Manumpil, Gilbert R; Tarore, Henny S, dan Keles, Dantje. (2019). Analisis Tingkat Kesehatan Bank dengan Menggunakan Metode CAMEL (Capital, Asset, Management, Earning, Liquidity) pada PT Bank Negara Indonesia (Persero) Tbk Tahun 2015-2017. Jurnal Administrasi Bisnis, Vol. 9, No 1, hlm 49-56. ((p-ISSN 2338-9605; e-2655206X).

Mulyani. (2018). Perjalanan Rupiah 2018, Babak Belur hingga Rp15.200/USD dan Akhirnya Menguat Lagi. Melalui https://idxchannel.okezone.com/read/2018/12/31/278/1998246/perjalanan-rupiah2018-babak-belur-hingga-rp15-200-usd-dan-akhirnya-menguat-lagi (01/01/2019)

Otoritas Jasa Keuangan. (2021). Laporan Publikasi Bank. Januari 04, 2021. https://www.ojk.go.id/id/kanal/perbankan/data-dan-statistik/laporan-keuanganperbankan/Default.aspx

Pandia, Frianto. (2012). Analisis Laporan keuangan. Rajawali Pers, Jakarta.

Purba, H.Y., Darminto, NP, M.W. (2015). Analisis CAMEL Untuk Menilai Performance Perusahaan Perbankan (Studi pada Bank-bank Milik Pemerintah yang Go Public di BEI). Jurnal Administrasi Bisnis. Vol. 29 No. 1 Desember 2015.

Saiya dan M. Pandowo. (2015). Analisis Keberadaan Perbankan Menggunakan Metode Camel (Studi Pt. Bank Mandiri-Persero Tbk Dari 2012 - 2014). Jurnal EMBA Vol.3 
No.2 Hal 132-140.

Saleo, Rika. (2017). Analisis Tingkat Kesehatan Bank dengan Menggunakan Metode CAMEL (Studi Kasus pada PT. Bank Mandiri). Jurnal EMBA,Vol.5 No 2, hlm. 2143 2149.

Saputra, H. (2016). Analisis Tingkat Kesehatan Bank Dengan Menggunakan Rasio CAMEL (Studi Kasus Pada Bank Rakyat Indonesia (Pesero) Tbk. Jurnal Skripsi, (Online), ( http://media.neliti.com )

Sekaran, U. dan Bougie R. (2017). Metodologi Penelitian untuk Bisnis Edisi 6. Salemba Empat. Jakarta.

Sugiyono. (2015). Penelitian Kuantitatif, Kualitatif dan R\&D. Bandung: Alfabeta.

Suryabrata, Sumadi. (2011). Metodologi Penelitian. Jakarta: Grafindo Persada.

Syahputra, Randi. (2018). Analisis Tingkat Kesehatan Bank dengan Metode CAMEL pada PT Bank Artos Indonesia Tbk periode 2014-2017. Jurnal Akuntansi dan Bisnis, Vol.4 (1), hlm. 49-63.

Tambuwun, C. J., \& Sondakh, J.J. (2015). Analisis Laporan Keuangan Sebagai Ukuran Kesehatan Bank Dengan Metode CAMEL Pada PT Bank Sulut. Jurnal EMBA Vol. 3 No. 2 Juni 2015, Hal.863-873. 